\title{
Occurrence of algal leaf spot (Cephaleuros virescens Kunze) on avocado in Goiás State, Brazil
}

\author{
Camila Vilela Vasconcelos ${ }^{1}$, Fabíola Teodoro Pereira ${ }^{1}$, Carolina dos Santos Galvão ${ }^{1}$, Daniel Diego Costa Carvalho ${ }^{1}$
}

${ }^{1}$ Universidade Estadual de Goiás (UEG), Laboratory of Plant Pathology, 75780-000, Ipameri, Goiás, Brazil.

Autor para correspondência: Daniel Diego Costa Carvalho (daniel.carvalho@ueg.br)

Data de chegada: 07/07/2015. Aceito para publicação em: 13/10/2015.

Fruit species are frequent targets of diseases, especially those caused by fungi and bacteria, while parasitic green algae are poorly studied. Algal leaf spot, caused by the pathogen Cephaleuros sp., specially occurs on the shaded leaves of the plant, when it is subjected to high temperature and humidity, causing indirect damage due to the reduced leaf photosynthetic area. On April 11th, 2014, a disease survey was carried out in a commercial orchard of avocado (Persea Americana Mill) in Perolândia, Goiás, Brazil (17³2'56.43”S, 52¹4’04.54”W, $858 \mathrm{~m}$ ), where leaves of adult plants were observed exhibiting orange spots of rounded shape, and velvety texture, scattered over the adaxial surface (Figure 1D).

Samples of symptomatic leaves were collected and sent to the Laboratory of Plant Pathology of Goiás State University (UEG) $\left(17^{\circ} 43^{\prime} 00.38^{\prime}\right.$ 'S $\left., 48^{\circ} 08^{\prime} 40.96^{\prime} \mathrm{W}, 796 \mathrm{~m}\right)$ for examination under a stereomicroscope. Slides were prepared by using sterile distilled water (SDW) as mounting medium, removing the mycelium and algal structures found on the infected tissue. Images of micromorphological structures were captured under a Leica DM500 light microscope, with an ICC50 digital camera. Algal structures were measured by using the LAS EZ (100x) software, obtaining the average of 40 measurements for each structure.

Measurement of the structures indicated $307.5-673.8 \times 12.0-20.1$ $\mu \mathrm{m}(477.0 \times 14.6 \mu \mathrm{m})$ for sporangiophores (SP) (Figure 1A), and 21.7 $-32.4 \times 15.2-23.1 \mu \mathrm{m}(27.7 \times 19.2 \mu \mathrm{m})$ for sporangia (S) (Figures 1A and $1 \mathrm{~B})$. The number of septa of sporangiophores varied from 4 to 8 (Figure 1A), with an average of 5.4 septa for each sporangiophore. The number of sporangia produced by each sporangiophore was 5 to 10 , with an average of 6.8 , of which 3.3 were attached and 3.5 detached from the suffultory cell (SC) of the sporangiophore (Figure 1C). The headcells (HC) had 29.8-59.8 x 30.1-58.1 $\mu \mathrm{m}$ (44.6 x $43.6 \mu \mathrm{m})$ (Figure 1C). These characteristics indicate that the algae occurring on avocado crop in Perolândia, Goiás, Brazil, is Cepaheluros virescens. Symptomatic leaves, used for the analysis, were herbalized and stored in the UEG's Herbarium of Plant Diseases under the registration number H-29-02.

\section{ACKNOWLEDGEMENT}

To CNPq, FAPEG and UEG for three fellowships.
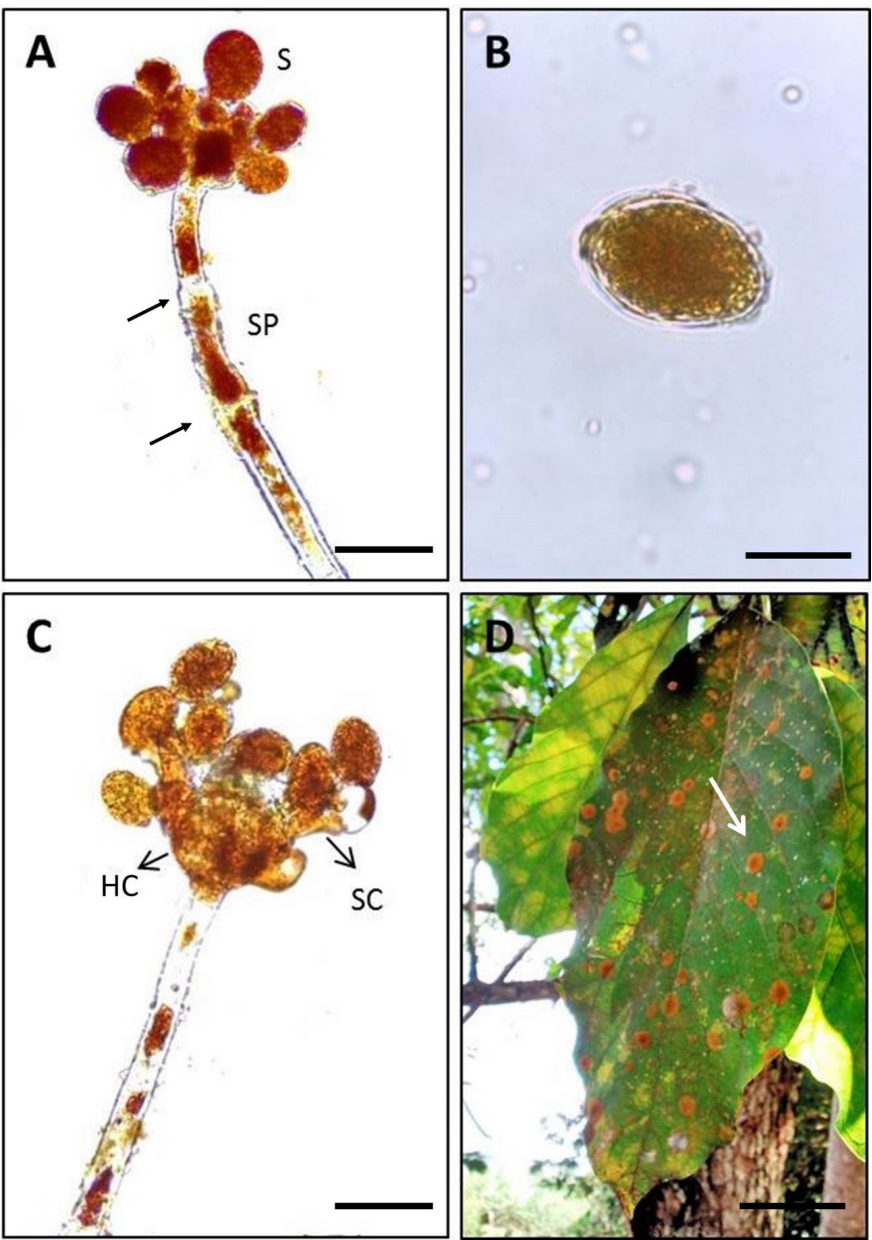

Figure 1. (A) SP - sporangiophore, S - sporangia, arrows indicate the septa of sporangiophore; (B) sporangia of Cephaleuros virescens in detail; (C) HC - head-cell, SC - suffultory cell; (D) Avocado leaf exhibiting rounded lesions of algal leaf spot. (Bars correspond to 70 $\mu \mathrm{m}, 20 \mu \mathrm{m}, 65 \mu \mathrm{m}$ and $14 \mathrm{~cm}$, respectively). 